\title{
Germany keeps up the squeeze on CERN
}

Munich. The European Molecular Biology Laboratory (EMBL) in Heidelberg and the Institut Laue-Langevin in Grenoble, Europe's biggest neutron source facility, have been reprieved from a threatened cut in Germany's subscriptions. Last week the German parliament's finance committee approved a revised 1997 budget which backs away from the cut and is expected to be adopted shortly by the full parliament.

But there has been no such rethink of planned cuts in its subscriptions to CERN, the European Laboratory for Particle Physics, and two other European research centres.

The pressure has been increased by a further reduction of DM160 million (US\$106 million) in the budget of the ministry of research. As a result, Germany remains committed to reducing its CERN subscription by 8.5 per cent in 1997 and 1998, and by 9.3 per cent in the following two years. Unless such reductions are accepted by CERN's other member states, German officials are said to be prepared to give notice to quit the organization. It would then reapply for membership under different conditions.

At present, Germany is the largest contributor to CERN, whose budget consists of contributions from 19 member states according to a fixed formula, based on gross national product. Germany's determination to pay less means either that it must be given a special dispensation to reduce its subscription unilaterally, or that other members must reduce their contributions in line with Germany's cut.

At a CERN committee of council meeting earlier this month, three scenarios were put forward outlining how the threatened
German cut could be best handled to avoid disrupting the construction of the Large Hadron Collider (LHC).

A proposal to allow Germany special dispensation found little support. The scenario most likely to win the backing of CERN's council when it meets next month would involve reducing the subscription of all members, in line with Germany's planned reduction, with the resulting budget shortfall being made up by a mixture of internal savings and cash-flow adjustments.

Some member states may be tempted by the third, compromise scenario. This would introduce cuts in all contributions more gradually, starting with 6.5 per cent next year and reaching 8.5 per cent in 1999. But officials of the German research ministry are determined to resist this option.

Germany has been only slightly more flexible in its attitude towards cuts in its subscription to the European Synchrotron Radiation Facility in Grenoble, whose 12 member states pay contributions according to a formula determined in 1988 that depends on estimated use of the facility. Since July, Germany has reduced its proposed cut from 10 per cent to 7 per cent, in line with a proposal from Italy.

Even at this level, the cut will have a severe impact. But the facility has just had some good fortune in the form of a FFr30million (\$5.8-million) out-of-court settlement with a construction firm responsible for providing faulty flooring in an experimental area. This gives member states time to renegotiate their contributions, and absorb the German cuts.

Initially, the German government had proposed cutting the subscription to EMBL next year by DM2 million (see Nature 382, $285 ; 1996)$. But it has now backed off from this proposal, in line with its decision to protect and promote its underdeveloped biotechnology industry.

The Institut Laue-Langevin, which is financed by France, Germany and Britain, has also been let off the hook. A planned German cutback of 7 per cent will not be imposed. One reason seems to have been the fact that the institute was forced to cut back on staff and experimental instruments by 20 per cent when Britain reduced its contribution in 1993. In addition, Germany is backing a deal, due to be signed shortly, to reprocess the institute's highly radioactive waste at $\mathrm{La}$ Hague in France.

Christopher Llewellyn Smith, CERN's director-general, said on Monday that the laboratory faced "difficult times ahead", but that a decision by the committee of council to approve single-stage construction by 2005 - previous planning had been based on two stages, ending in 2008 - was "good news for CERN and for particle physics."

Alison Abbott \& David Dickson

\section{NIH retains research funds for the future}

Washington. The US National Institutes of Health (NIH) has decided to celebrate a bumper funding year by holding back some of the money for spending in future years raising alarm bells among biomedical research lobbyists who fear that such caution will deter Congress from increasing NIH funding in the future.

NIH officials say that a plan to issue about 300 multi-year grants, out if its total of 7,000 new grants to be issued in 1997 , will provide stability for the young researchers eligible for the money. They argue that these researchers will not have to worry about any future cuts in the agency budget. But the strategy has the extra advantage, from NIH's point of view, that some of the 1997 money will thus pay for research done in 1998 or 1999.

In each year of the first Clinton administration, Congress has managed to get NIH to spend more money than the administration wanted; in 1997, for example, the administration asked for 4 per cent increase and the Congress granted almost 7 per cent — an extra \$300 million.

Tony Mazzachi of the American Association of Medical Colleges says that his organization has yet to decide its position on the funding plan, although he adds that "we are concerned about it". Other biomedical research lobbyists warned that the change could undermine the momentum for growth in the NIH budget.

Colin Macilwain 